\title{
Undergraduates and Online Purchasing Behavior
}

\author{
Syuhaily Osman (Corresponding author) \\ Centre of Excellent for Sustainable Consumption Studies \\ Faculty of Human Ecology, Universiti Putra Malaysia, Malaysia \\ Tel: 60-3-8946-7109 E-mail: syuhaily@putra.upm.edu.my \\ Benjamin Chan Yin-Fah \\ Faculty of Human Ecology, Universiti Putra Malaysia, Malaysia \\ Bei Hooi-Choo \\ Faculty of Human Ecology, Universiti Putra Malaysia, Malaysia
}

\begin{abstract}
This study examined the attitude towards online purchasing behavior among UPM students. A purposive sampling method was used and the sample comprised of 100 students who studying at Universiti Putra Malaysia (UPM). Data were collected via self-administered questionnaire. The questionnaire consisted of four sections: respondents' socio-demographic background, attitude, purchase perception and website quality. Results indicated that majority of respondents had moderate level of purchase perception and website quality towards online purchasing. Pearson correlation was used to measure the relationship between age, purchase perception, website quality and attitude towards online purchasing behavior. The finding revealed that purchase perception and website quality were significant relationship with attitude towards online purchasing behavior. However the finding showed that age has no significant relationship with attitude towards online purchasing behavior. The result of the study showed that there was a significant difference in attitude towards online purchasing behavior by gender and education background. The study concluded that gender, education background, purchase perception and website quality have directly influence on attitude towards online purchasing behavior. Further studies should explore other factors that influence attitude towards online purchasing behavior with a broader range of population and higher representativeness sampling method.
\end{abstract}

Keywords: Online purchasing behavior

\section{Introduction}

The internet exerts an increasingly strong influence on people's everyday life. The growth of interest in the internet as a shopping and purchasing medium is fascinating for practitioners and researchers alike. Its rapid growth poses intriguing questions for academics research. Some researchers proposed that the consumer's own characteristics play an important role in his/her propensity to engage in internet transactions (Jarvenpaa and Grazioli, 1999). Menawhile, marketers have identified many factors that influence a consumer's purchases decision and online buying behavior (Goldsmith, Bridges and Freden, 2001; Vellido. Lisboa and Meehan, 2000). Jarvenpaa and Todd (1996-97) classify these factors into four clusters of purchase perception that influence a consumer's purchasing decision. These clusters of purchase perception are: product understanding, shopping experience and customer service and consumer risk. Product understands, often called product perception, serves as the primary determinate of where consumers choose to shop (Cronin, 1996). Price, product quality and product variety are the most influential product perceptions cited in the literature (Arnold, Handelman and Tiger, 1996). Shopping experience is the second cluster of determine and product availability, effort, lifestyle compatibility and playfulness or enjoyment of the shopping process (Bhatnagar, Misra and Rao, 2000; Liu, Armett, Capella and Taylor, 2001). Customer service, the third cluster that influences purchase decision, includes vendor, responsiveness, assurance and reliability. Economic, social, performance, personal and privacy risk dimensions are typically included within consumer risk, the fourth cluster of purchase perceptions (Park and Fader, 2001).

According to previous studies, consumers' characteristics and goals have been found to influence their behaviors such as purchasing, revisiting intentions, and attitudes toward a website ( $\mathrm{Wu}, 2003)$. In addition, consumer 
characteristics are of the factors affecting their behavior. They are an innate part of their makeup, i.e., the way they describe themselves and label others. Demographic characteristics, such as gender, age, and ethnicity are examples of background characteristics (Wu, 2003). For instance, Mohd Suki (2006) his study found that internet shoppers among Malaysia are more likely to be young, affluent, highly educated and wealthy. Many previous online purchasing researches had focused on benefits of online stores that put forward success (Muylle, Moenaert and Despontin, 2004; Shih, 2004). In the context of online purchasing, benefits are what consumers think an online store can offer them (Keller, 1993). Prior studies have also examined the benefits that encourage consumers to purchase through the internet (Narges, Laily and Ali, 2009). Therefore, understanding how consumers perceive benefits of online store is important in choosing and making a purchase decision.

The development of the internet has increased the popularity of online purchasing. Internet users encounter many different purchasing systems and user interfaces, some with substantial variation and purpose. Despite this variety, each individual develops a generalized impression of the internet purchase process. Personal experiences combined with information communicated by others form the basis for developing an image in the mind's eye of the individual (Martineau, 1957). According to Internation Data Corporation (IDC), online purchasing consumer's spending was growing from $\$ 118$ billions worldwide in 2001 to $\$ 707$ billions in 2005 (Wolverton, 2001). E-business revenue was grow from $4 \%$ of companies' total revenue worldwide in 2000 to $7 \%$ in 2001. In line with the same scenario, Malaysian needs to take cognizance of these trends and react fast in order to be an active participant in the emerging electronic world.

Taylor Nelson Sofres (2001) found that $24 \%$ of the total adult populations in Malaysia were internet users in 2001. Males are the dominant internet users and the proportion of adult population that used internet was the highest amongst 15 to 20 years old followed by the 20 to 29 years old (39\%). The rapid growth in numbers of internet users in Malaysia provides a bright prospect for e-marketers. With the impressive increase in the rate of growth in personal computer penetration estimated at $18 \%$, Malaysia is expected to lead the internet growth in Asia where e-commerce can be developed. It was projected that by 2006 subscribers to the internet will increase by four folds from the present 1.8 million (New Straits Times, 2001). This rapid growth in the number of internet users had promoted a belief in many business circles that the web represents a huge marketing opportunity (Hoffman, 2000). The future of e-commerce seems to be very bright for Malaysia accordingly.

\section{Purpose and Significant of the Study}

In light of the ongoing paradigm shift form traditional (brick and mortar store) to internet-based purchases, a question arises as to whether the same factors that have been found to influence traditional purchases similarly influence internet-based purchases. Thus, the purpose of this study is to describe the factors that affecting online purchasing behavior among college students. The significant of the study can be viewed from various perspectives. From the consumer perspective, this research can bring benefit to them by letting them know that there are many advantages of online shopping such as convenience (save time, save energy), have a broader selection, more cheaper price, and can access to the product information before buying. This research hopefully could make the consumers aware that the e-commerce is become an important trends in this modern information technology society so that they know that there are others shopping choices instead of in- store traditional shopping. From the marketer prospective, this research is important to alert the online vendor about the factors that influence or encourage the online shopping behavior among consumers. For example, the vendor characteristics and the website quality are the factors that the marketer or the online vendor need to concern. The online vendor needs to perform good characteristics, trustable and provide good services after sale (especially in warranty issues). They can put more details information about the product they are selling in their website or make their website more interesting to attract more consumers to buy so that they can maximize their profit. Finally, the results of this research could hopefully improve the general knowledge about online shopping and could become a reference to the future researcher.

\section{Literature Review}

\subsection{Online Purchasing}

Electronic commerce has become one of the essential characteristics in the internet era. According to UCLA Center for Communication Policy (2001), online shopping has become the third most popular internet activity, immediately following e-mail using or instant messaging and web browsing. It is even more popular than seeking out entertainment information and news, two commonly thought of activities when considering what internet users do when online. Of internet users, $48.9 \%$ made online purchasing in 2001, with three-quarters of purchasers indicating that they make 1-10 purchases per year. When segment into very versus less experienced internet users, the very experienced users average 20 online purchases per year, as compared to four annual 
purchases for new users (UCLA Center for Communication Policy, 2001). There is now ample evidence that the internet has changed the way in which consumers purchase goods and services (Forsythe and Shi, 2003). Consumers are not interested in the technology per se but how the internet can improve their shopping experiences and helps them make better decision (Burke, 2002). Swaminathan, White and Rao (1999) found that consumers who are primarily motivated by convenience are more likely to make purchase online. Bellman, Lohse and Johnson (1999) examine the relationship among demographics, personal characteristics and attitude towards online shopping. These authors found that people who have a more "wire lifestyle" and who are more time-constrained tend to buy online more frequently, i.e., those who use the internet as a routine tool and/or those who are more time starved prefer shopping on the internet. Bhatnager et al., (2000) have explored how demographics, vendor/service/product characteristic and website quality influence the consumers' attitude towards online shopping consequently their online buying behavior. The same study indicated that the convenience the internet affords and the risk perceived by the consumers are related to the consumers' attitudes and behavior positively and negatively.

\subsection{Attitude towards Online Purchasing Behavior}

Consistent with the literature and models of attitude change and behavior (Fishbein and Ajzen, 1975), it is believed that consumer's attitudes will affect intention to shop online and eventually whether a transaction is made. First, it refers to the consumers' acceptance of the internet as a shopping channel (Jahng, Jain and Ramamurthy, 2001). Secondly, it refers to consumer's attitudes toward a specific internet store (i.e., to what extent consumers think that shopping at this store is appealing). These first two dimensions are negatively associated with the third, customers' perceived risk. According to Lee, Park and Ahn (2001), two main categories of perceived risk emerge in the process of online shopping. The first is the perceived risk associated with product/service and includes functional loss, financial loss, time loss, opportunity loss, and product risk. The second is the perceived risk associated with context of online transactions, and includes risk of privacy, security, and no repudiation. Among them, the influence of financial risk, product risk, and concern for privacy and security are significant (Senecal 2000; Borchers 2001; Bhatnagar et al. 2000). However, the fourth dimension of attitude, consumers trust in the stores, can reduce perceived risk. Using a qualitative analysis, Wolfinbarger and Gilly (2001) suggest that two motives, i.e., shopping for fun (hedonic) and shopping with a goal in mind (utilitarian) are typical of online shoppers. Hedonic shoppers are motivated by their involvement with a class of products that directs their browsing the internet through auction sites and visit to hobby-related sites. In other words, the hedonic shopper typically seeks a product specific online shopping experience. Alreck and Settle (2002) found that internet shopping was viewed as saving more time than traditional modes of shopping. Bhatnagar et al., (2000-2001) found that for those who use online information sources of buying financial products, time availability was not associated with the propensity to conduct and online search for or purchase of these products. That is, those who were pressured for time did not use online purchasing more than those who were not pressured for time. Jarvenpaa, Tractinsky and Vitale (2000) investigate how consumers' perceived store size and reputation influence their trust in the store, risk perception, attitudes and willingness to buy at the specific store. The study found that there is a positive correlation between consumer trust in internet stores and the store's size and reputation. Consumer with higher trust may reduces perceived risk associated with internet shopping and thus, this will eventually generates more favorable attitude towards shopping at the particular store and this lead to willingness to buy from the store.

\subsection{Factors Affecting Attitude toward Online Purchasing Behavior}

Previous e-commerce purchasing research examined numerous demographics characteristics. For example, Bhatnager et al., (2000) examined ages, gender, marital status and years on the internet in a previous study on risk, convenience and the internet shopping behavior. They found that marital status has no effect on purchase behavior and found mixed results based upon gender (except for specific gender-related products), years on the internet and age. Other studies report those e-commerce purchasers are younger, more educated and have higher income than do non e-commerce purchases (Ratchford, Talukdar and Lee, 2001). Korgaonkar and Wolin (1999) found that motivational factors as well as age and gender impacted the likelihood of online purchasing. In their study, older males were the group that had the highest online purchase behavior. This is consistent with the results of Donthu and Garcia's (1999) research, who found that older internet users were more likely to buy online when compared to younger users, even though the younger users had more positive attitudes towards internet shopping. Dholakia and Uusitalo (2002) found that younger consumers reported more hedonic and utilitarian benefits of online shopping than older consumers. In contrast, Joines, Scherer and Scheufele (2003) found that younger respondents were more likely to shop online. 
In terms of gender, although there was no significant difference between online shopper and non-shoppers in terms of gender (Donthu and Garcia, 1999), men were found to make more purchases (Li, Kuo and Russell, 1999; Stafford, Turan and Raisinghani, 2004) and spend more money online (Susskind, 2004) than women. Men's perceptions on online shopping were approximately the same as (Alreck and Settle, 2002) or even more favorable than (Slyke, Comunale and Belangar, 2002) those of female consumers. Women were reported to have a higher level of web apprehensiveness (i.e., individual's resistance to or fear of the "www" as a channel for context-free online information seeking and communication) (Susskind, 2004). Being more skeptical about e-business than their male counterparts, women were emotionally less satisfied with online shopping and mad fewer online purchases than men (Rodgers and Harris, 2003). On the other hand, Citrin, Stem, Spangenberg and Clark (2003) found that women demonstrate a stronger need for tactile input in product evaluation than men (Citrin, Stem, Spangenberg and Clark, 2003). The inability to touch or try on products, a shortcoming of online purchasing, might also result in fewer female online shoppers. Li, et al. (1999) found that men used more frequent online shopping than women and well-educated consumers were the frequent web buyer. They also found that consumers with high incomes used more frequently internet for shopping. Other studies have also indicated that men, more highly educated and higher income groups are more likely to buy online than women, the less well education, and lower groups (Forsythe and Shi, 2003; Li et al, 1999; Swinyard and Smith, 2003).

\subsection{Purchase Perception towards Online Purchasing Behavior}

Perceptions might be able to influence consumers' purchase decisions and this topic has been widely documented in the context of traditional consumer behavior literature. Jarvenpaa and Todd (1996-97) clustered e-commerce purchase perceptions into four general categories, i.e., product perception, shopping experience, customer service and consumer risk. In the product perception, price is defined as the total monetary cost to the consumer for the purchases. Pricing perceptions are important since new pricing strategies are being applied to goods and services sold over the internet. Dynamic pricing, defined as a pricing strategy where prices change over time, across customers or across product bundles can easily be executed on the internet (Kannan and Kopalle, 2001). This pricing strategy contrast with conventional retail channels where pricing changes are traditionally performed over the course of weeks or months (Kannan and Kopalle, 2001). Shopping experience is a mixture of, lifestyle compatibility, effort playfulness and fun (Goldsmith, 2000; Liu, et al., 2001; Ratchford, et al., 2001). When engaged in e-commerce purchases over the internet, effort is primarily a mental activity; shoppers work at their keyboard instead of having to plan for and travel to multiple shopping sites. Lifestyle compabilility encompasses the consumers' lifestyle and shopping habits (Vellido, et al., 2000). In addition, lifestyle compability may reflect on the consumer's opinion of those that make e-commerce purchases (Goldsmith and Bridges, 2000). Playfulness and the perception of "fun" take into account the shopper's overall satisfaction with the shopping experience (Goldsmith, et al., 2001). Unnecessary shopping time and the inability to locate in-stock products of the desired color and size are example of occurrences that diminish the shopping experience.

Customer service affects purchase decisions through vendor knowledge, responsiveness and reliability (Gefen, 2002). In high- to medium-contact contexts, service personnel are integral to service delivery to customers, noting that their attitudes and behaviors during the service encounter strongly influence customer satisfaction, loyalty and behavioral intention (Hartline and Ferrell, 1996). Continued interaction between the customer and the service worker can lead to the development of a relationship between the parties. Meanwhile, consumer risk refers to the possibility that the consumer will be harmed or injured by either the product or by the shopping process. Credit card security is the predominant example of a personal risk inherent in e-commerce purchase transactions (Goldsmith and Bridges, 2000). Privacy risk reflects the degree to which a consumer may sacrifice their privacy when they are required to provide confidential information in the course of making a retail e-commerce transaction (Bhatnagar et al., 2000; Vijayasarathy, 2002).

\subsection{Website Quality}

Twenty studies investigate the relationship between website quality and consumers online shopping attitudes and behavior from different point of view. Zhang, von Dran, Small and Barcellous (2000) and Zhang and von Dran (2000) make an attempt to evaluate website quality from user satisfaction and dissatisfaction perspectives. Their studies showed that website design features can be regarded as hygiene and motivation factors that contribute to user dissatisfaction and satisfaction with a website. Hygiene factors are those whose present make a website functional and serviceable, and whose absence causes user dissatisfaction. Some of hygiene factors were: Privacy and Security, Technical Aspect, Navigation, Impartially and Information Content. Motivation factors are those that add value to the website by contributing to user satisfaction. In their continued effort, they further discovered that the most important website quality factors ranked by e-commerce consumers were hygiene 
factors (Zhang, von Dran, Small and Barcellos, 2000; Zhang and von Dran 2001; Zhang, von Dran, Blake and Pipithsuksunt, 2001). Within the web environment, computer factors are those whose presence provides functionality. Liang and Lai (2001) review website quality factors influencing Internet buying behavior by categorizing them into three groups, two of them are also named hygiene factors and motivating, and third media named richness factors. Liang and Lai (2001) categorized these elements, including technical aspects, navigation, impartially and information content as computer factors. Overall, the measures employed to value website quality by past researchers include the websites' information content, information presentation, interaction between customers and venders, navigation, searching mechanism, security, site technical feature, media richness and so forth (Cho, Im, Hiltz and Fjermestad, 2001; Grandon and Ranganthan, 2001; Ho and Wu, 1999; Kim, Eom and Yoo, 2001; Koufaris, Kambil and LaBarbera, 2002).

\section{Methodology}

A convenience sampling method was conducted among 100 Universiti Putra Malaysia (UPM) students outside the university's main library. The team of researcher has chosen this sampling method because of the unavailability of the list students visiting the library and thus, it is impossible to get the absolute number of the patrons. Besides, researchers can meet different students from different faculty at the library. This is to avoid bias for surveying all the respondents from only a certain faculty. For sample saiz consideration, there are about 25 thousand in-campus students in Universiti Putra Malaysia in year 2009 and according to the Salant and Dillman (1994), 96 cases is just sufficient to represent the total sample of 25 thousand using 50:50 split approach and with \pm 10 sampling error. Even though this small sample might not able to representative of all the population, they are considered appropriate for sampling as using a relatively more homogeneous group and this is helpful to minimize random error that might occur by using a heterogeneous sample such as the general public (Calder, Philips and Tybout, 1981).

Pre-test was done prior to the natural research. This pre-test was involved 10 respondents in order to ensure that the question were understandable by the actual respondents. It was also aimed to determine the reliability alpha for each instruments used beside to achieve precise research objectives. In addition, pre-test allows the researcher to improve the scarify that existed in questionnaire form and to make sure that the items was suit the study's requirement. In order to obtain data, self-administered questionnaire was used for this study. In addition, the questionnaire was conducted in English. This survey was take place from $5^{\text {th }}$ of Jan 2009 to $12^{\text {th }}$ of Jan 2009 at Perpustakaan Sultan Abdul Sultan UPM.

\subsection{Instrumentation}

The main instrument for this study was a questionnaire. The questionnaire was aimed to gather information about respondents' background, hours a day use the internet, how long they had been on the internet, their level of online shopping experiences, how long they have been shop online and the types of goods that they tend to buy online. Thereafter, the questionnaire was used to assess knowledge of online purchasing. The questions were developed based on a literature review which found to have high readability and good validity. The questionnaire was divided into four parts. In part A, respondents were asked to answer the questions about their socio-demographic background such as age, gender, race, religion and some questions regarding their internet usage and previous online purchasing experience. In part B, each respondent were asked to complete fourteen questions regarding their attitude towards online purchasing. The questions were conducted using five points ordinal scale ranging from 1 = "Strongly Disagree" to 5 = "Strongly Agree". Higher scores indicated more positive attitude towards online purchasing. Part $\mathrm{C}$ did focus on the perception towards online purchasing and respondents were asked to complete 29 questions regarding the purchase perception when they do the online purchasing. The questions were conducted using five points ordinal scale ranging from 1 = "Strongly Disagree" to 5 = "Strongly Agree". The last part of the questionnaire was related with the website quality. Respondents were asked to complete ten questions regarding the website quality that influence them to do online shopping. The question was conducted using the five points ordinal scale ranging from $1=$ "Strongly Disagree" to $5=$ "Strongly Agree".

\section{Research Finding and Discussion}

\subsection{Profile of the Respondents}

In this study, $77 \%$ of the respondents were female and $23 \%$ were male and the age of the respondents were ranged from 20 years old to 28 years old. Most respondents were in the age of 23 years old which $46 \%$ and the minimum percentage was on age 20 years old, 26 years old and 28 years old which only $1 \%$ respectively. For ethnicity and religious, most respondents were Chinese $(60 \%)$ and the most religion also was Buddha $(58 \%)$. In this research finding, there was one Siamese and 3\% respondents were Christian. The totals of $93 \%$ of 
respondents were holding the undergraduate level of education. Looking at the patterns of internet usage, $35 \%$ of the respondents have used internet more than four hours in a day. When being asked how long have been on internet, $75 \%$ respondents revealed that they have averagely four years experience in net-serving. This result concluded that many people are using internet now and more of them are adult. For online purchasing behavior, $43 \%$ of respondents were in the beginner level of online purchase and $23 \%$ respondents have 6 months to 1 year online purchase experiences. The goods they typically bought from internet are books (38\%), cloths (37\%), travel booking (35\%) and computer hardware (33\%). Meanwhile, the least types of goods they tended to buy are toys/collectibles $(10 \%)$. The result indicated that many people have purchased online and most of them were in beginner level because the electronic commerce has become one of the essential characteristics in the internet era. As from previous study ACLA Center for Communication Policy (2001) found that online purchase has become the third most popular internet activity.

\subsection{Purchase Perception towards Online Purchasing}

In this study, more than half of the respondents agreed that online purchasing easy for them to observe other shopping over the World Wide Web (55\%). Beside, more than half of the respondents also agreed that shopping over the World Wide Web would allow them to do their shopping more quickly (53\%). However, more than half of them disagreed that shopping over the World Wide Web would be a safe way to shop (53\%).

\subsection{Website Quality as the Factors Influencing Online Purchasing}

Website quality is depending on dimension of quality. High quality website has dimension of timeliness, accuracy and consistency and performance. Timeliness means the websites change often and rapidly. Accuracy and consistency answer the question where the data presented to the user accurate enough. Lastly, good performance means the browser connection quick to respond to an e-commerce purchase. From the table 9, it showed that most of the respondents agreed that when shopping online, they often purchase at the website which can provide them more information of product and selection (77\%). Beside, most of the respondents also agreed that they often purchase at the website which assure them of safety and easy of navigation and order $(76 \%)$.

\subsection{Attitude towards Online Purchasing}

An attitude is a hypothetical construct that represents an individual's degree of like or dislike for an item. Attitudes are generally positive or negative views of a person when make online purchase. There were total of 14 items used to measure the respondents' attitude towards online purchasing. The responses were scored by five points ordinal scale. This study found that most of the respondents agreed that shopping on the internet saves time (74\%). However, most of them also agreed that shopping online is risky (72\%). Most of respondents (51\%) have medium level of attitude towards online purchasing, where as there were only $6 \%$ of the respondents has high level of attitude towards online purchasing.

\subsection{Correlation and Differences between the Selected Variables}

Pearson correlation test was utilized to examine the relationship between the independent variable i.e., age, purchase perception, website quality and attitude towards online purchasing behavior. The study found that there was no significant relationship between age and attitude towards online purchasing behavior among the respondents $(r=0.165, p>0.05)$. This current finding was inconsistent with previous research findings which found that e-commerce purchases are younger than do non e-commerce purchases (Ratchford et al., 2001). The research revealed that there was a significant relationship between purchase perception and attitude towards online purchasing behavior among respondents $(\mathrm{r}=0.616, \mathrm{p} \leq 0.01)$. Therefore, Ho4 was successfully rejected. This current finding was consistent with previous study which found that perceptions believed to influence consumer's purchase decision (Jarvenpaa and Todd, 1996-97). From the Table 11, the research found that there was a significant relationship between website quality and attitude towards online purchasing behavior among respondents $(r=0.343, p \leq 0.01)$. Similar with past findings, Liang and Lai (2001) suggest that website quality influenced internet buying behavior by categorizing them into motivator, hygiene and media richness factors.

In terms of differences, T-test was utilized to examine the differences between online purchasing behavior among male and female students. Mean for male was a bit higher than mean for female, with 45.30 and 40.61 respectively. Meanwhile, the One-way ANOVA test was utilized to examine the differences between online purchasing behavior among education background. The study also found that that there was a significant difference in attitude towards online purchasing behavior among the male and female students $(t=3.979, p \leq$ 0.01). Li et al. (1999) found that men used more frequent online shopping than women. However, this result was inconsistent with past research which found that there was no significant difference between online shopper and non-shopper in terms of gender (Donthu and Garcia, 1999). Besides, there was a significant difference in attitude 
towards online purchasing behavior among three levels of education background $(\mathrm{F}=8.346, \mathrm{p} \leq 0.01)$. This finding was consistent with previous study which found that e-commerce purchaser are younger, more educated and has higher income than do non e-commerce purchases (Ratchford et al., 2001).

\section{Conclusion, Implication and Recommendation}

Online shopping has becoming a popular activity today because of the ease and large population of people using information technology tools and internet. Everyone can online nowadays by using the information technology tools such as notebook, PDA, computer or even hand phone if the hand phone can support the WIFI function. Many cafeterias, fast food restaurants and supermarkets have provide the WIFI service for customer to surf the internet in order to attract the consumer to spend longer time in their shop. With the growing number of people purchasing online, it is important to determine the attitude towards online purchasing behavior. In addition, this study also examines three factors: socio-demographic background, purchase perception and website quality that influence attitude towards online purchasing behavior. The results of this study have several implications that would beneficial to marketers, consumers and future research. From the marketer's perspective, they will more understand the attitude towards online purchasing behavior among UPM students as well as the factors affecting the attitude towards online purchasing behavior. From the result, they can know that purchase perception and website quality of respondents have significant relationship with attitude towards online purchasing behavior. In addition, they also can win the confidence of the consumers and also understand potential customer's behavior. Besides, they also can know that the customers who purchase online are more likely to buy books, cloths, travel booking and computer hardware. From the consumer's perspective, the consumers will know that there are many advantages of online purchasing such as convenience (save time, save energy), have a broader selection, cheaper price and can access to the product information before buying. This research can make the consumers aware that e-commerce is become an important trends in this modern information technology society. This study is also useful to academicians where current study could serve as a reference and may provide some guides for researchers who would like to study about the same topic.

This study has taken important steps to investigate the attitude towards online purchasing behavior and the factors affecting the attitude towards online purchasing behavior. Despite this study has strengths, it has certain limitations. First, the limitation of the data prevents further exploration of the study. There were only 100 respondents whom have been participated in this study using convenience sampling. The respondent represents early adulthood only, i.e., all respondents are undergraduate students in Universiti Putra Malaysia, Selangor. Different stages of life cycles of respondents would yield different results as different education level. Future researchers are suggested to implement more representativeness sampling method and increasing the sample size variety especially in respondents' age to decrease the error for the purpose of the generalizing result to a wider population. Second, future researchers may further scope to replicate the study in different environment and different geographical locations. Different environment played an important factor that affect respondents behavior specifically working environment. Working individuals could behave in a different manner compared with this sample. This study was conducted on Universiti Putra Malaysia. Therefore, it could not represent other people in urban or rural areas where the quality of life and approaches are different. Last but not least, this research has only examines three factors that influence online purchasing behavior. Future researchers are suggested to determine other factors that influence online purchasing behavior beside the socio-demographic, purchase perception and website quality. Therefore, it can help them to understand other factors that may influence the online purchase behavior.

Despite the high growth potential of retail e-commerce and ongoing interest in online purchase in Malaysia, there is still lack of understanding concerning the characteristics of online shoppers in Malaysia and its potential impact on consumer marketing. This is mainly attributed to the fact that online purchase is rather new in Malaysia and just beginning to take its place as an alternative shopping channel for consumers to shop for goods and services. This new emerging concept of retailing has captured the interest of retailers and businesses, financial institutions, telecommunication service providers, government officials and even consumers because by virtue of its unique characteristics. Online purchase has the potential of becoming a dominant alternative shopping channel in the near future that cannot be easily challenged by the conventional retailing method. No one can predict how successful e-commerce will be in this competitive market. Online purchase is supplementary or complementary to existing business as an additional marketing, promotion and fulfillment channel. This research demonstrates that online shoppers were motivated by multiple types of factors, including demography, purchase perception and website quality. Furthermore it provides insights into the UPM students' online purchase behavior, which may be essential for online retailers in order to provide better services and penetrate broader into online selling market. 


\section{Acknowledgement}

I want to express my appreciation to my undergraduate student, Mss. Bei Hooi-Choo in converting her final year project paper into this paper. Knowing that there are rooms of improvement in this paper but her first attempt in publication should be given supports and encourages.

\section{References}

Alreck, P. and Settle, R. (2002). The hurried consumer: time-saving perceptions of internet and catalogue shopping. Journal of Database Marketing, 10(1), pp. 25-35.

Arnold, S. J., Handelman, J. and Tiger, D. J. (1996). Organizational legitimacy and retail store patronage. Journal of Business Research. 35, pp. 229-239.

Bellman, S., Lohse, G. and Johnson, E. (1999). Predictors of online shopping behavior. Communications of the ACM. 42(12), pp. 32-38.

Bhatnagar, A., Misra, S. and Rao, H. R. (2000). Online risk, convenience and internet shopping behavior. Communications of the ACM. 42(11), pp. 98-105.

Borchers, A. (2001). Trust in Internet shopping: A test of a measurement instrument. Proceedings of the 7th Americas Conference on Information Systems, 11, pp. 799-803.

Burke, R. R. (2002). Technology and the customer interface: What consumer want in the physical and virtual store. Journal of the Academy of Marketing Science, 30(4). 13, pp. 441-432.

Calder, B. J., Philips, L. W. \& Tybout, A. (1981). Designing research for application. Journal of Consumer Research, 8(Sept), 197-207.

Cho, Y., Im, I., hiltz, R., and Fjermestad, J. (2001). Causes and outcomes of online customer complaining behavior: implications for customer relationship management (CRM). Proceedings of the $7^{\text {th }}$ Americas Conference on Information Systems, 6, pp. 900-907.

Citrin, A. V., Stem Jr., D. E., Spangenberg, E. R. and Clark, M. J. (2003). Consumer Need for Tactile Input: An Internet Retailing Challenge. Journal of Business research, 56(11), pp. 915-923.

Cronin, M. J. (1996). Global advantage on the World Wide Web. New York: Van Nostrand Reinhold.

Dholakia, R, and Uusitalo, O. (2002). Switching to electronic stores: consumer characteristics and the perception of shopping benefits. International Journal of Retail and Distribution Management, 30(30), pp. 459-69.

Donthu, N. and Garcia, A. (1999). The internet shopper. Journal of Advertising Research, 39(3), pp. 52-9.

Fishbein, M., and Ajzen, I. (1975). Belief, attitude, intention, and behavior: An introduction to theory and research. Reading, Massachusetts: Addison-Wesley.

Forsythe, S. M. and Shi, B. (2003). Consumer patronage and risk perceptions in internet shopping. Journal of Business Research, 56, pp. 867-875.

Gefen, D. (2002). Customer loyalty in e-commerce. Journal of Association for Information System, 3, pp. 27-50.

Goldsmith, R. E. and Bridges, E. (2000). E-talling vs retailing: Using attitudes to predict online buying behavior. Quarterly Journal of Electronic Commerce, 1(3), pp. 245-253.

Goldsmith, R. E., Bridges, E. and Freden, J. (2001). Characterizing online buyer: Who goes with the flow? Quarterly Journal of Electronic Commerce, 2(3), pp. 189-197.

Goldsmtih, R. E. (2000). How innovativeness differentiates online buyers. Quarterly Journal of Electronic Commercial, 1(4), pp. 223-333.

Grandon, E. E., and Ranganathan, C. (2001). The impact of content and design of web sites on online sales. Proceedings of the $7^{\text {th }}$ Americas Conference on Information Systems, 5, pp. 920-926.

Ho, C. and Wu, W. (1999). Antecedents of consumer satisfaction on the internet: an empirical study of online shopping. Proceedings of the $32^{\text {nd }}$ Hawaii International Conference on System Sciences, 8, pp.38-45.

Hoffman, D. L. and Novak, T. P. (1996). Marketing in the hypermedia computer-mediated environments: Conceptual foundations. Journal of Marketing, 60, pp. 50-68.

Hoffman, D. L. and Novak, T. P. (1997). A new market for paradigm for electronic commerce. Information Society, 13, pp. 43-54.

Hoffman, D. (2000). The revolution will not be televised. Marketing Science, 19, pp.1-3. 
Jahng, J., Jain, H. K. and Ramamurthy, K. (2001). Product complexity, richness of web-based electronic commerce systems and system success: A proposed research framework. Proceedings of the $5^{\text {th }}$ Americas Conference on Information System., 4, pp. 520-522.

Jarvenpaa, S. L. and Grazioli, S. (1999). Surfing among the sharks: How to gain trust in the cyberspace. Financial Times Supplement, 15 March.

Jarvenpaa, S. L. and Todd, P. A. (1996-97). Consumer reactions to electronic shopping on World Wide Web. International Journal of Electronic Commercial, 1(2), pp. 59-88.

Jarvenpaa, S. L., Tractinsky, N. and Vitale, M. (2000). Consumer trust in an internet store. Information Technology and Management, 1, pp.45-71.

Joines, J., Scherer, C. and Scheufele, D. (2003). Exploring motivations for consumer web use and their implications for e-commerce. Journal of Consumer Marketing, 20(2), pp. 90-108.

Kannan, P. K. and Koppalle, P. K. (2001). Dynamic pricing on internet: Important and implications for consumer behavior. International Journal of Electronic Commercial, 5(3), pp. 63-83.

Keller, K. L. (1993). Conceptualizing, measuring and managing customer-based brand equity. Journal of Marketing, 57, pp.1-22.

Kim, E. B., Eom, S. B., and Yoo, S. (2001). Effective user interface design for online stores in the Asia Pacific region: A survey study. Proceedings of the $7^{\text {th }}$ Americas Conference on Information Systems, 4, pp. 867-872.

Korgaonkar, P. and Wolin, L. (1999). A multivariate analysis of web usage. Journal of Advertising Research, 38(1), pp. 7-21.

Koufaris, M., Kambil, A., and LaBarbera, P. A. (2002). Consumer behavior in web-based commerce: and empirical study. International Journal of Electronic Commerce, 6(2), pp. 115-138.

Lee, D., Park, J., and Ahn, J. (2001). On the explanation of factors affecting e-commerce adoption. Proceedings of the 22nd International Conference on Information Systems, 6, pp. 109-120.

Li, H., Kuo, C., Russell, M, G. (1999). The impact of perceived channel utilities, shopping orientations and demographics on the consumer's online buying behavior. Journal of Computer Mediated Communication, 5, pp. $23-50$.

Liang, T. and Lai, H. (2001). Effect of store design on consumer purchase: an empirical study of on-line bookstore. 39, pp.431-444.

Liu, C., Armett, K. P., Capella, L. M. and Taylor, R. D. (2001). Key dimensions of web design quality as related to consumer response. Journal of Computer Information System, 42(1), pp. 70-82.

Martineau, P. (1957). Motivation and advertising. New York: McGraw-Hill.

Mohd Suki, N. (2006). A descriptive investigation of Malaysian Internet user's adoption of online shopping. Journal of Information Technology \& Multimedia, 3, pp. 127-138.

Muylle, S., P., Moenaert, and M., Despontin. (2004). The conceptualization and empirical validation of web site user satisfaction. Information \& Management, 41, pp.543-60.

Narges D., Laily H.P. and Ali K. (2009). Developing an Instrument for Measurement of Attitude Toward Online Shopping. European Journal of Social Sciences, 7(3), pp. 166-177.

New Straits Times. (2001). Malaysia: Study to rate IT skills of civil servants. 19 March 2001

Park, Y. and Fader, P. S. (2001). Modeling browsing behavior at multiple websites. Cambridge (NY): Wharton School, University of Pennsylvania.

Ratchford, B. T., Talukdar, D. and Lee, M. S. (2001). A model of consumer choice of the internet as an information source. International Journal of Electronic Commercial, 5(3), pp. 7-22.

Rodgers, S. and Harris, M. (2003). Gender and E-Commerce: An exploratory study. Journal of Advertising Research, 43(3), pp. 322-330.

Senecal, S. (2000). Stopping variables in online buying processes: An innovation diffusion approach. Proceedings of the 6th Americas Conference on Information Systems, 5, pp. 1380-1385.

Shih, H.P. (2004). An empirical study on predicting user acceptance of e-shopping on the web. Information \& Management, 41, pp. 351-68. 
Slyke, C. V., Comunale, C. L. and Belangar, F. (2002). Gender differences in perceptions of web-based shopping. Communications of the ACM, 45(7), pp. 82-86.

Stafford, T. F., Turan, A. and Raisinghani, M. S. (2004). International and Cross-Cultural Influences on Online Shopping Behavior. Journal of Global Information Management, 7(2), pp.70-87.4.

Susskind, A. (2004). Electronic commerce and World Wide Web apprehensiveness: An examination of consumers' perceptions of the World Wide Web. Journal of Computer-Medicated Communication, 9(3), pp. $78-90$.

Swaminathan, V., White, E.L. and Rao B.P. (1999). Browsers or buyers in cyberspace? An investigating of factors influencing electronic exchange. Journal of Computer Mediated and Communication, 5(2), pp. 122-134.

Swinyard, W. R. and Smith, S.M. (2003). Why people (don't) shop online: A lifestyle study of the Internet consumer. Psychology and Marketing, pp.567-597.

Taylor Nelson Sofres Sdn Bhd. (2001). TNS interactive - global e-Commerce report - July 2000. [Online] Available : http://worldwide.tnsofres.com/ger/malaysia.htm.

UCLA Center for Community Policy. (2001). The UCLA Internet report 2001: Surveying the digital future-year two. [Online] Available: http://www.ccp.ucla.edu/pdf/UCLA-Internet-Report-2001.pdf.

Vellido, A., Lisboa, P. J. G. and Meehan, K. (2000). Quantitative characterization and prediction of online purchasing behavior: A talent variable approach. International Journal of Electronic Commerce, 4(4), pp. $83-104$.

Vijayasarathy, L. R. (2002). Internet taxation, privacy and security: Opinions of the taxed and legislated. Quarterly Journal of Electronic Commercial, 3(1), pp. 53-71.

Wolverton, T. (2001). Return Purchase Study: Online problems could deter customers. [Online] Available: http://malaysia.cnet.com/news/2001/03/22/20010322j.html CNET News.com. (June 15, 2000).

$\mathrm{Wu}$, S.L. (2003). The relationship between consumer characteristics and attitude toward online shopping. Marketing Intelligence and Planning, 21, pp. 37-44.

Zhang, P., and von Dran, G. M. (2000). Satisfactor and dissatisfactors: A two-factor model for website design and evaluation. Journal of the American Society for Information Science, 51(4). pp 1253-1268.

Zhang, P. and von Dran, G. (2001). User expectations and ranks of quality factors in different website domains. International Journal of Electronic Commerce, 6(3), pp. 9-34.

Zhang, P., von Dran, G. M., Small, R. V. and Barcellos, S. (2000). A two-factor theory for website design. Proceedings of the $33^{\text {rd }}$ Annual Hawaii International Conference on System Sciences.

Zhang, P., von Dran, G.M., Blake, P. and Pipithsuksunt, V. (2001). Important design features in different web site domains. E-Service Journal, 1(1), pp 77-91. 
Table 1. Patterns of Using Internet and Buying Online

\begin{tabular}{|c|c|c|}
\hline Variable & $\begin{array}{l}\text { Frequency } \\
(\mathrm{n}=100)\end{array}$ & $\begin{array}{c}\text { Percentage } \\
(\%)\end{array}$ \\
\hline \multicolumn{3}{|l|}{ Hours a day use Internet } \\
\hline Less than 1 hours & 7 & 7 \\
\hline 1-2 hours & 20 & 20 \\
\hline 2-3 hours & 19 & 19 \\
\hline 3- 4 hours & 19 & 19 \\
\hline More than 4 hours & 35 & 35 \\
\hline \multicolumn{3}{|c|}{ How long have been on internet } \\
\hline Less than 6 months & 1 & 1 \\
\hline 6 months - 1 year & 1 & 1 \\
\hline 1-2 years & 3 & 3 \\
\hline 2-3 years & 2 & 2 \\
\hline 3-4 years & 18 & 18 \\
\hline More than 4 years & 75 & 75 \\
\hline \multicolumn{3}{|c|}{ Level of online shopping experience } \\
\hline None & 4 & 4 \\
\hline Beginner & 43 & 43 \\
\hline Intermediate & 35 & 35 \\
\hline Expert & 18 & 18 \\
\hline \multicolumn{3}{|c|}{ How long have been shopping online } \\
\hline Less than 6 months & 18 & 18 \\
\hline 6 months - 1 years & 23 & 23 \\
\hline 1-2 years & 12 & 12 \\
\hline 2-3 years & 14 & 14 \\
\hline 3-4 years & 19 & 19 \\
\hline Over 4 years & 12 & 12 \\
\hline \multicolumn{3}{|c|}{ Types of goods tended to buy } \\
\hline Music/DVD/Video & 19 & 19 \\
\hline Electrical equipment & 23 & 23 \\
\hline Travel booking & 35 & 35 \\
\hline Cloths & 37 & 37 \\
\hline Books & 38 & 38 \\
\hline Computer hardware & 33 & 33 \\
\hline Software/games & 15 & 15 \\
\hline Toys/Collectibles & 10 & 10 \\
\hline
\end{tabular}


Table 2. Descriptive Analysis of Attitude towards Online Purchasing

\begin{tabular}{|c|c|c|c|c|}
\hline No. & Variable & $\begin{array}{c}\text { Disagree } \\
(\%)\end{array}$ & $\begin{array}{c}\text { Neutral } \\
(\%)\end{array}$ & $\begin{array}{l}\text { Agree } \\
(\%)\end{array}$ \\
\hline 1 & I think shopping on the internet saves time. & 10 & 16 & 74 \\
\hline 2 & $\begin{array}{l}\text { It is a great advantage to be able to shop at any time of the } \\
\text { day on the internet. }\end{array}$ & 10 & 21 & 69 \\
\hline 3 & It is more difficult to shop on the internet. & 29 & 37 & 34 \\
\hline 4 & $\begin{array}{l}\text { I prefer traditional/conventional shopping to online } \\
\text { shopping. }\end{array}$ & 9 & 23 & 68 \\
\hline 5 & Shopping online is risky. & 11 & 17 & 72 \\
\hline 6 & $\begin{array}{l}\text { I believe online shopping will eventually supersede } \\
\text { traditional shopping. }\end{array}$ & 20 & 51 & 29 \\
\hline 7 & $\begin{array}{l}\text { I will prefer online shopping only if online prices are lower } \\
\text { than actual price. }\end{array}$ & 15 & 21 & 64 \\
\hline 8 & $\begin{array}{l}\text { A long time is required for the delivery of products and } \\
\text { services on the internet. }\end{array}$ & 14 & 35 & 51 \\
\hline 9 & Selection of goods available on the internet is very broad. & 14 & 34 & 52 \\
\hline 10 & $\begin{array}{l}\text { The description of products shown on the web sites are very } \\
\text { accurate. }\end{array}$ & 29 & 50 & 21 \\
\hline 11 & $\begin{array}{l}\text { The information given about the products and services on the } \\
\text { internet is sufficient. }\end{array}$ & 22 & 53 & 45 \\
\hline 12 & Online shopping is as secure as traditional shopping. & 58 & 29 & 13 \\
\hline 13 & $\begin{array}{l}\text { Internet reduces the monetary costs of traditional shopping to } \\
\text { a great extent (parking fees etc.). }\end{array}$ & 12 & 29 & 59 \\
\hline 14 & $\begin{array}{l}\text { I would be frustrated about what to do if I am dissatisfied with } \\
\text { a purchase made from the internet. }\end{array}$ & 5 & 29 & 66 \\
\hline
\end{tabular}


Table 3. Descriptive Analysis of Purchase Perception towards Online Purchasing

\begin{tabular}{|c|c|c|c|c|}
\hline No. & Variable & $\begin{array}{c}\text { Disagree } \\
(\%)\end{array}$ & $\begin{array}{c}\text { Neutral } \\
(\%)\end{array}$ & $\begin{array}{l}\text { Agree } \\
(\%)\end{array}$ \\
\hline 1 & Shopping over the Web would enhance my effectiveness at shopping. & 18 & 45 & 37 \\
\hline 2 & It is easy for me to observe others shopping over the web. & 10 & 35 & 55 \\
\hline 3 & $\begin{array}{l}\text { Shopping over the Web would require me to purchase equipment which } \\
\text { would be beyond my financial means. }\end{array}$ & 28 & 42 & 30 \\
\hline 4 & Shopping over the Web fits into my shopping style. & 40 & 37 & 23 \\
\hline 5 & I would have no difficulty telling others about the results of online shopping & 22 & 44 & 34 \\
\hline 6 & Shopping over the Web would increase my shopping productivity. & 33 & 34 & 33 \\
\hline 7 & I have had plenty of opportunity to see others shopping over the web. & 20 & 38 & 42 \\
\hline 8 & I am able to experiment with shopping over the web as necessary. & 29 & 30 & 41 \\
\hline 9 & $\begin{array}{l}\text { I would have difficulty explaining why shopping over the web may or may } \\
\text { not be beneficial. }\end{array}$ & 27 & 39 & 34 \\
\hline 10 & I would trust online vendors enough to feel safe shopping over the web. & 50 & 28 & 42 \\
\hline 11 & $\begin{array}{l}\text { Shopping over the Web would be expensive since it would require me to pay } \\
\text { for access to the Internet. }\end{array}$ & 41 & 37 & 22 \\
\hline 12 & $\begin{array}{l}\text { Before deciding whether to shop over the web, I was able to properly try it } \\
\text { out. }\end{array}$ & 14 & 42 & 44 \\
\hline 13 & $\begin{array}{l}\text { Shopping over the web would allow me to have better item selection in my } \\
\text { shopping. }\end{array}$ & 23 & 38 & 39 \\
\hline 14 & I could afford to buy the equipment needed to shop over the web. & 24 & 36 & 40 \\
\hline 15 & Shopping over the Web would improve my image with those around me. & 31 & 36 & 33 \\
\hline 16 & $\begin{array}{l}\text { I would trust an Internet service provider with transmitting personal } \\
\text { information necessary for me to shop over the web. }\end{array}$ & 42 & 26 & 32 \\
\hline 17 & Shopping over the Web is not very visible. & 10 & 38 & 52 \\
\hline 18 & $\begin{array}{l}\text { Shopping over the Web would be completely compatible with my current } \\
\text { situation. }\end{array}$ & 28 & 50 & 22 \\
\hline 19 & Shopping over the Web would give me greater control over my shopping. & 35 & 34 & 31 \\
\hline 20 & Shopping over the Web would be a safe way to shop. & 53 & 27 & 20 \\
\hline 21 & Shopping over the Web would require a lot of mental effort. & 30 & 41 & 29 \\
\hline 22 & $\begin{array}{l}\text { I could afford to pay a monthly fee to an Internet service provider in order to } \\
\text { shop over the Web. }\end{array}$ & 30 & 38 & 32 \\
\hline 23 & Shopping over the Web would allow me to do my shopping more quickly. & 22 & 25 & 53 \\
\hline 24 & People who shop over the Web have greater prestige than those who do not. & 30 & 48 & 22 \\
\hline 25 & $\begin{array}{l}\text { Shopping over the Web would be compatible with all aspects of the way I } \\
\text { shop. }\end{array}$ & 23 & 53 & 24 \\
\hline 26 & $\begin{array}{l}\text { I believe I could communicate to others the consequences of shopping over } \\
\text { the Web. }\end{array}$ & 25 & 33 & 42 \\
\hline 27 & Shopping over the Web would improve my shopping abilities. & 26 & 34 & 40 \\
\hline 28 & Overall, I believe that shopping over the Web would be easy to do. & 19 & 30 & 51 \\
\hline 29 & Shopping over the Web would allow me to get better prices when shopping. & 18 & 42 & 40 \\
\hline
\end{tabular}


Table 4. Descriptive Analysis of Website Quality

\begin{tabular}{|c|l|c|c|c|}
\hline No. & Variable & $\begin{array}{c}\text { Disagree } \\
(\%)\end{array}$ & $\begin{array}{c}\text { Neutral } \\
(\%)\end{array}$ & $\begin{array}{c}\text { Agree } \\
(\%)\end{array}$ \\
\hline $\mathbf{1}$ & $\begin{array}{l}\text { I am cautious in trying new website and would rather stick with } \\
\text { a website I usually buy or familiar with. }\end{array}$ & 16 & 29 \\
\hline $\mathbf{2}$ & $\begin{array}{l}\text { I feel that familiarity with the website prior to purchase reduce } \\
\text { the risk of undertaking an online shopping. }\end{array}$ & 5 & 28 & 67 \\
\hline $\mathbf{3}$ & $\begin{array}{l}\text { I often seek out the advice of my friends regarding which } \\
\text { website to buy as not to make a wrong decision. }\end{array}$ & 11 & 29 & 60 \\
\hline $\mathbf{4}$ & $\begin{array}{l}\text { When shopping online, a powerful brand name of an e-retailer } \\
\text { can entrust me and enhance my confidence on my choice. }\end{array}$ & 12 & 19 & 69 \\
\hline $\mathbf{5}$ & $\begin{array}{l}\text { When shopping online, I often go an buy on a website I } \\
\text { experienced and familiar with. }\end{array}$ & 6 & 24 & 70 \\
\hline $\mathbf{6}$ & $\begin{array}{l}\text { When shopping online, I often purchase at the website which } \\
\text { can provide me more information of product and selection. }\end{array}$ & 3 & 20 & 30 \\
\hline $\mathbf{7}$ & I enjoy taking chances in trying new and different website. & 29 & 35 & 56 \\
\hline $\mathbf{8}$ & $\begin{array}{l}\text { I seek related information and knowledge about various } \\
\text { website from professional associations, experts, friends, family } \\
\text { members and work associates. }\end{array}$ & 9 & 20 & 76 \\
\hline $\mathbf{9}$ & $\begin{array}{l}\text { The web enhances my effectiveness in products searching and } \\
\text { buying. }\end{array}$ & 4 & 38 & 58 \\
\hline $\mathbf{1 0}$ & $\begin{array}{l}\text { When shopping online, I often purchase at the website which } \\
\text { assure me of safety and easy of navigation and order. }\end{array}$ & 4 & 20 \\
\hline
\end{tabular}

